потинй состав C-концсвого аргиннслдержащего триптисского пептнда ным составом фрагмента и суммой составов пептидов Т3, Т4, Т35 и Тб7. Сравнивая выходы субфрагментов из пептида $\operatorname{Tm} 2$ (см. табл. 2), можио предположить, что при частичном гидролизе модифицированиых по итаткам пнзна пептидов предложенным методом расщеплине иде пренмицестенно по остаткам маленл-лизнн. Однако не полноctio paəpyшаются связи Lys-Val и Lys-Pro. Mы полагасм, что остатки

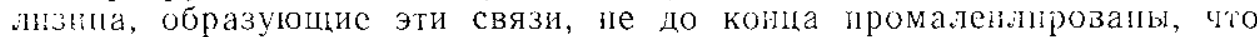

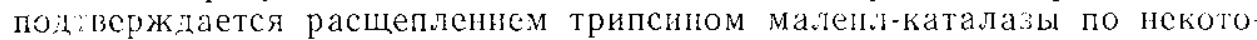
рым остаткам лnзнна (см. пептиды $\operatorname{Tm} 3, \operatorname{Tm} 5, \operatorname{Tn} 19$ и др. в табл. 1). liдропиз пентида Тm2 идет также по остаткам аспарагнновой кислоты If в исзначительной степсни - по остаткам других аминокислот.

Ирнведеншые в табл. 246 пептидов насчитывают 686 остатков аминокислот. Амннокис.птные последовательности 19 пептидов (подчеркнуты в табл. 1) перекрываются с таковымн другнх пептндов. 36 пептндов $\mathfrak{c}$ уннкальными аминокислогными последоватсльностямн $\mathrm{co-}$ держат 561 остаток, что составляет $81 \%$ полипептнднӧ цепи каталазы.

Sil un a 5 . Partial or complete amino acid sequence of 46 tryptic peptides irom maleyl-catalase was deicrmined. 36 unique peptides comprise 561 amito acid residues and accuunt for $81 \%$ of the catalase polypeptide chain.

\title{
CIICOK ЛHTEPATYPU
}

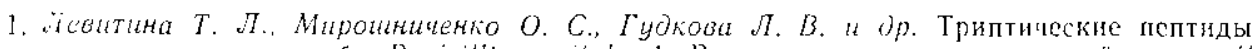

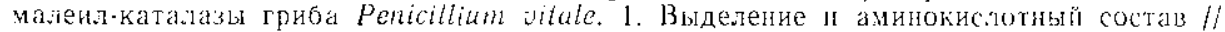
Биопогіимеры и кпека.-1993.-9, мі 1.- С. $5--8$.

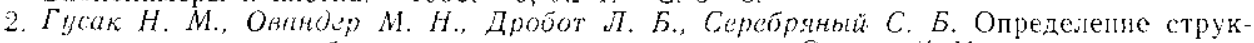
туры пептидов комбинированиым методом дансил-Эдман // Методы молекуляр. бнологин. - Киев : Наук. думка, 1979.- С. 142.153

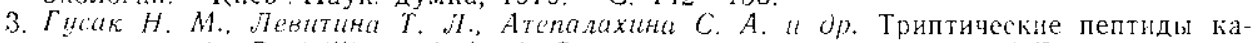
ráaзы грнба Pencillam vitale. 3. Строение некоторых пептдов // Биополимерл и кuteтka. 1989. - 5, № 1.-.. C. 45-51.

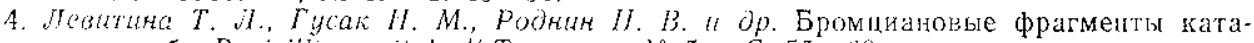

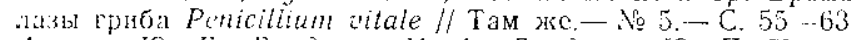

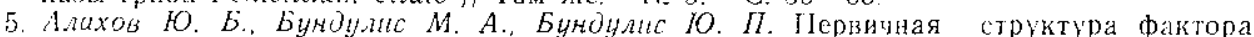
зиогация $G$ из $E$. coli. IV. Структура пептдов броминанового расщенления могткуль G-фактора // Биоорг. хиния.--1983.-9, № 3.- C. 304-31.1.

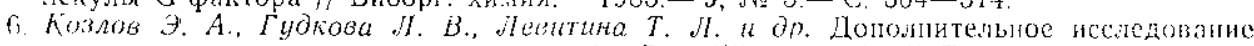

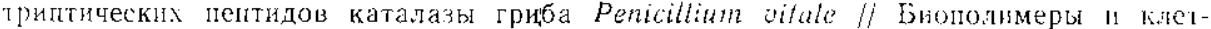
ка.-1993. 9. № 1.-C. $22-25$.

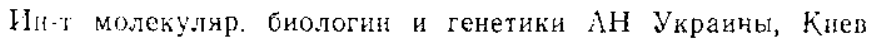

Ho.1yueiso 24.07 .92

y, 2 K

\section{В. И. Древаль}

\section{ВЈИЯНИЕ ИОНИЗИРУ ЮЩЕГО ИЗЈУЧЕНИЯ НА БЕЛОК- ЛИПИДНЫЕ КОМПЛЕКСЫ ЛИПОСОМ}

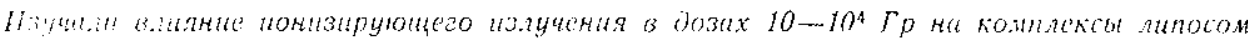

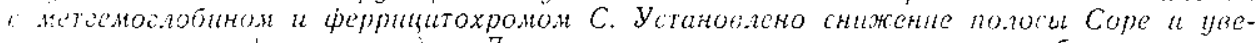

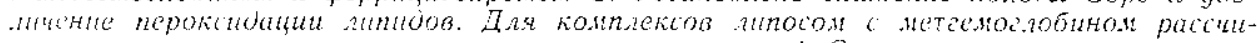

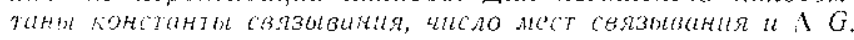

Введенде. К пастоящему времени установлена важная роль мсморан клетки в реализации поражаюшего действия раднациі па организм

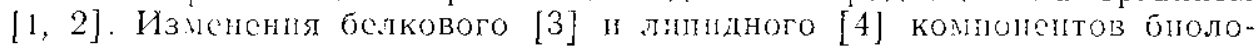
(с) ВЗ. И. Древаль, 1993 
гических мембран сопровождаются нарушениями структурной органнзации мсмбран [5]. В работе [6] это объясняется процессами кооперативных переходов белок-липидного матрикса мембран в результате изменения белок-липидыых взаимодействий. Ранее были получены дан. шые о характере взанмодействия метгемоглобнна и феррнцигохрома С с линидами в липосомах $[7,8]$. Особенности радиационного повсдения $[9,10]$ и биологических функций гсмопротеидов $[11,12]$ дают оспование предположить, что при облучении они могут оказывать определен. ное влияние на формирование радиационных повреждений в белок-ли-
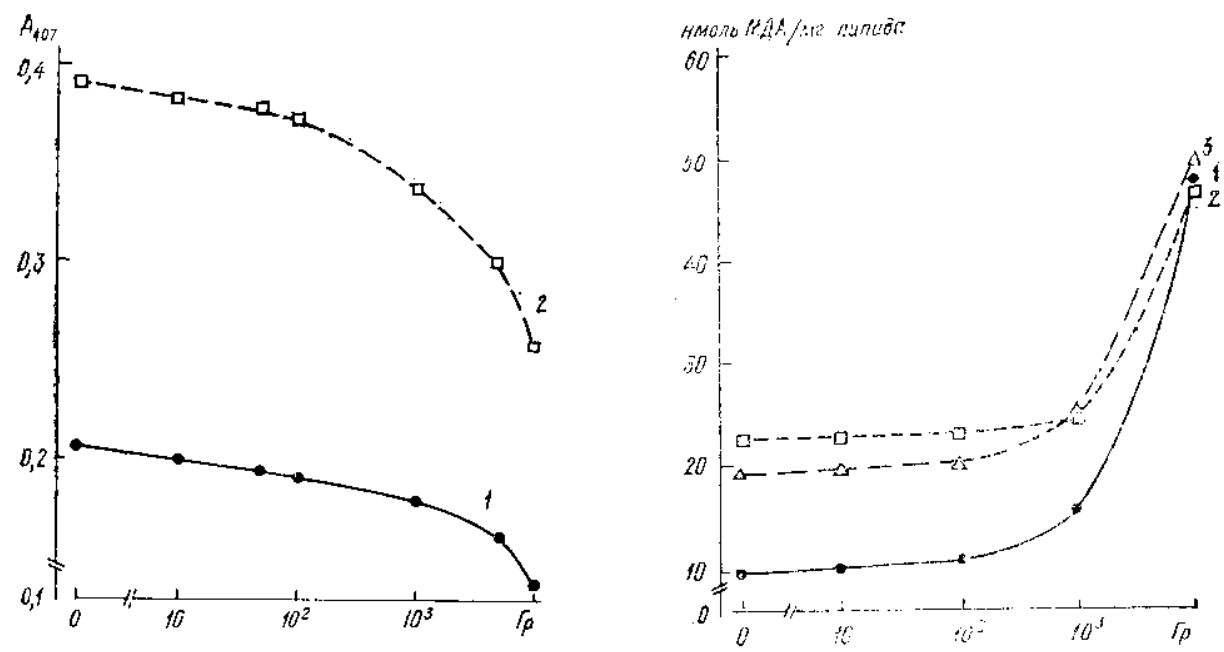

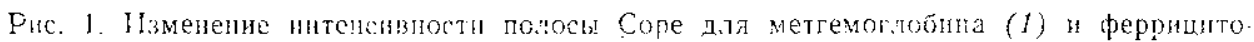
xрона $\mathrm{C}(2)$ лри облучениі .1нпосом

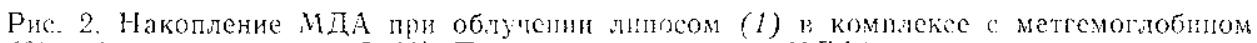
(2) и феррицитохромом С (3). По вертикалн нмоль Мгдамг пипнда

пидном комплексе мембран. В связи с этим в настоящем сообщенин исследовали влияние иопизируюпей радиации на белок-липчдиые комплексы метгемоглобнна и феррицитохрома С с липосомамп.

Материалы и методы. Суммарные фосфолипнды выделяли из желтков куриного sйла по методу [13]. Везикулярныс мсмбраны готови-

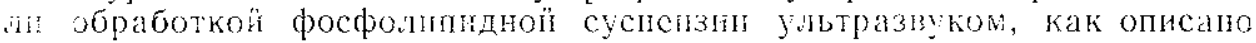
pariec [7].

Метгемоглобнн получали, окисляя $1,2 \mathrm{M}$ феррициандом калия окспемогиобин, выдсленый из крсын чсловека [14], с последуюпей гельфильтрацией на молселекте G-25.

Для связывания метгемоглобина и феррищитохрома C («Реахим») с липосомами использовали буфер $(0,01 \mathrm{M}$ трис-HCl, pH 7,4$)$, содержащиї $0,15 \mathrm{M} \mathrm{NaCl}\left(25^{\circ} \mathrm{C}, 90\right.$ мин). Концентрация липнда в пробс $8 \mathrm{~m} /$ мл. Мольнос отношение липид: белок варьировали от $2: 1$ до $1: 10$ Липосомы с адсорбированным метгемоглобнном отделяли от свободного метгемоглобина гель-фильтрацией на колонке с сефадексом G-200 $(1 \times 20 \mathrm{~cm}$, скорості, фильтрации $5 \mathrm{mл} / 4)$. Для определениял количества связанного с липосомами метгемоглобина везнкулы прсдварительно солюбилизировали 0,1\%-м DS-Na. Концентрацию белка регистрировали по методу Лоури и соавт. [15] на СФ-46 при 750 нм.

Концентрацио продуктов перекисного окисления липидов паходили по рсакции с 2-тнобарбитуровой кислотой при длине волиы 535 нм $\left(\varepsilon=1,56 \cdot 10^{5} \mathrm{M}^{-1} \mathrm{~cm}^{-1}\right)$ [16] и выражали в концентраци малонового диаиі,дегида (МДА) па 1 мг мембрапного липида.

Обработку экспериментальных данных с использованием $t$-критерия Стьюдента и расчсты коэффициента корреляцин $(r)$ [17] осуществпяли на ЭВМ «Искра-1030».

Облучение проводили на линейном ускорителе электронов энергн єей $5 \mathrm{M \ni B} \mathrm{в} \mathrm{дозах} 10,50,10^{2}, 10^{3}, 5 \cdot 10^{3}$ ні $10^{4} \Gamma$ p. 
Результаты и обсуждение. Степснь радиационно-химпческих изменсний связаниых с липосомами гсмсодержащих белков метгемоглобнна н феррицитохрома $\mathrm{C}$ определяли по интенсивности оптицеской плогпости в области полосы Сорс (407 гм). Можно видеть (рис. 1), что воздействис ионизйрующего излучения приводит к спижению интенсивности полосы Соре. Это согласустся с полученными ранее данными $[18,19]$. По уровно содержания МДА в липосомах (рис. 2) можно судить о возрастании процессов перекисного окисления липндов с увеличегием дозы понизирующего излучения. Расчсты коэффициента корреляции величниы интенсивности полосы Соре для метгсмоглобина и феррицитохрома С и содержания МДА в липосомах $(r=-0,944$ и $-0,980$ соответственно) указывают иа взаимообусловленность этих процессов. Таким образом, полученные данные позволяют заключить, џто воздействие ионизнрующего излучения па белок-липцные комплексы липосом вызывает изменение структуры белков и нарастание героксидации липидов.

Для апализа влняния раднациі на процессы взанмодействия бслког и липидов в мембране липосомы и метгемоглобин облучали в дозс $10^{3} \Gamma$ р, после чего изучали их связывапне. Исследованы следуюшие комобннацип: нсоблученный метгсмоглобин +нсоблученные липосомы; бблучснный метгемоглобин +необлученные липосомы; необлучепиый метгемоглобин -облученные липосомы; облучениый метгемоглобин + †облучепные липосомы. Константу связывапия $\left(K_{a}\right)$ и чнсло мест связызания $(N)$ рассчитывали по методу наименыних квадратов в коорминатах уравнения Скетчарда: $R / C=K_{a} \cdot N-K_{a} \cdot R$, где $R-$ мольное соотншение метгемоглобина и фосфолипида в белок-липидиом комияксе; $C$ - концентрация белка [20]. Изменение свободной энергип определяли по формулс $\Delta G=-R T \ln K_{a}$. Полученные результаты приведсны в таблице. Можно отметить, что связывапие облученного метгемоглобина с суспензисй нсоблучснных липосом приводит к возрастанню числа мест связывания на $24 \%(p<0,05)$ по сравнснию с контро.тем (необлугеный метгемоглобин +необлученныс липосомы), константа связывапя при этом достоверно не изменяется. Связывание пеоблу"епного мстгемоглобна с облученными лидосомами вызываст снижеинс $K_{a}$ 1з 2,6 раза $(\mathrm{p}<0,01)$, а $N$ увсличивается в 1,8 раза $(\mathrm{p}<0,01)$. Связывание облученіого метгсмоглобнна с облученными липосомами

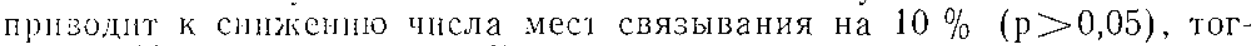
ia kak $K_{a}$ возрастаст на $32 \%(p<0,05)$.

Полагают, что радиационное поражение гемоглобина в растворе согровождастся конформацнонымі перестройками в сго структурной организацин под влиянием прямэго дсйствия радиации [10]. Ранее установлено [8], "го взанмодействие метгемоглобипа с фосфолипиднымн ззинулами определяется изменениями в структуре липидного бислоя. Нзвестно, что появленис в жирнокпслотных цепях гидроперекисных группировок приводиг к нарушению комплексообразования зипяда $c$ бслком [21]. Очевидно, наблюдаемыс при воздействии нонизирующей радиации активация процессов перекисного окисления липидов в липосомах и модифнкация структуры мстгемоглобина вызывают пзмене-

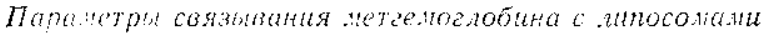

\begin{tabular}{|c|c|c|c|}
\hline Қомпонент комплекса & $K_{a} \cdot 10^{2}, M^{-1}$ & $N \cdot 10^{-2}$ & $\Delta G$, идж/моль \\
\hline 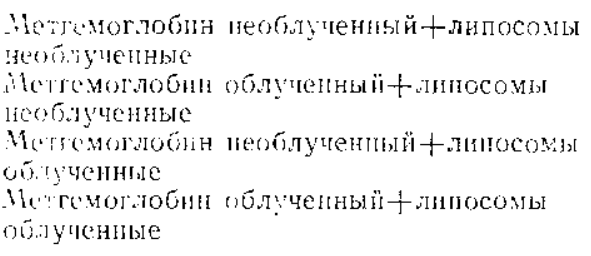 & $\begin{array}{l}7,04 \pm 0,49 \\
6,20 \pm 0,37 \\
2,75 \pm 0,05 \\
9,29 \pm 0,78\end{array}$ & $\begin{array}{l}0,68 \pm 0,05 \\
0,84 \pm 0,09 \\
1,25 \pm 0,16 \\
0,61 \pm 0,(14\end{array}$ & $\begin{array}{l}-16,25 \\
-15,93 \\
-13,92 \\
-16,94\end{array}$ \\
\hline
\end{tabular}


ние белок-липидных взаимодействий, обусловленных структурным соответствием белков и липидов в мембране [22]. Результаты изучсния связывания липосом и метгемоглобнна позволяют прсдположить, что нестабильность белок-липидных взанмодействий прн воздсйствии нопизирующего излучения на мембраны в значительной мере зависит от липндного компонента.

S $11 \mathrm{~m}$ in a $\mathrm{r} y$. The elfect of ionization radiation in doses $10-10^{4} \mathrm{Gr}$ on complexes liposomes with methemoglobin and ferricytochrone $C$ has been investigation. It was show: decrease sripe jore and increase lipid peroxidation. For complexes liposumes will; nethonghlobin constante of binding, number places of binding and $A$ G was calculii...t.

\section{СПИСОК ЛИТЕРАТУРЫ}

1. Поливода Б. Н., Конев В. В., Попов Г. А. Бноризиеские аспекты радиацноного поражения биомембран.- М. : Энергоитомиздат, $1990 .-160$ с.

2. Kудрянов во МГУ, $1982-304 \mathrm{c}$

3. Pыскилова C. T. Радиационная биология плазматических мембран-М.: Наука, $1989 .-\cdots 120 \mathrm{c}$

4. Kололийцева . K. Радиационная биология мембранных липидов.-. М. Наука, $1989-120$

5. Dоненко B. C., Акоев И. Г. Структурные изменения піазматических мембран под действием ионизирующей радиации // Успехи соврем. биологии.- 1982.-93, di 2.-C. $183-193$.

6. Benga $G$. Holmest $R$. Interactions betwecn components in biological membranes and implications for membrane funclion // Progr. Biophys. and Mol. Biol.- 1984—. 43.- P. $195-255$.

7. Горӧенко Г. П.. Древаль В. Н. Взаимодействне метгемоглобнға с фосфолипидын ми везикулами // Биополимеры и клетка.- 1990.- 6, 느 2.- С. $87-90$.

8. Древаль В. И., Горбенко $Г$. П. Влияние метгемоглобина и феррицитохрома С на структуру іниндиого бислоя // Укр. бнохим. журн., - 1990.-62, ㅊo 5.- С. і11. 114 .

9. Анирасова $M$. И. Радиацнонное окисление цитохрома С в водиых растворах // Радиобнология.-1972.- 12, № 4.- С. 578-582.

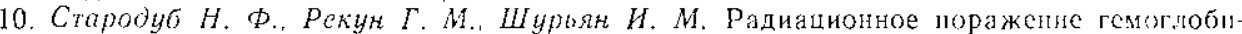
па.-- Киев: Науук. думка. 1976.-129 с

11. Коржуев $\Pi$. А. Гемогообин.- М. : Наука, 1964.- 146 с

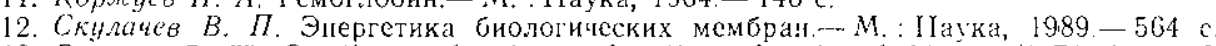

13. Dawson R. W. On the mechamism of action of phosphokinase // Biochem. J... $1963 .-88, \mathrm{~N} 3 .-\mathrm{P} .414-423$.

14. Розенбере Г. Я., Вязова Е. П., Иванова Г. Н. и ор. Полученис очншснного препарата гемоглобина и изучение его свойств // Пробл. Гематологин и переливания крови - 1975-20, № 11 - P. 25--29.

15. Lowry O., Rosebrough W., Farr A., Randall $R$. Protein measurement with the Folin phenol reagent // J. Biol. Chem.-1951. - 193, N 1.- P. 265-279

16. Владимиров ских мембранах.-- М. : Наука, 1972.-- 252 с

17. Закс Л. Статнстическое оценивание - M. : Статистика, 1976. 598 .

18. Амирагова $M$. Н. Структура, функции и радиолиз гемопротендов // Радиац. поражение и восстановление структур и функцй макромолекул. М.: Медицина 1977.-C. $80-120$

19. Lymn K. R., Raoult $A$. $P$. The effect of gamma-irradiation on solutions of catalase apocatalase // Int. J. Radiat. Biol.- 1973.- 24.- P. 25-31.

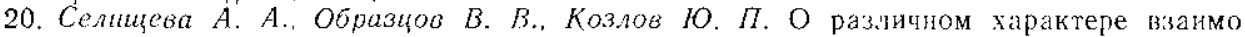
лё̈ствия окисленного и восстановленного цитохрома C $\mathrm{C}$ фосфолипидными везнкулами // Биохимия.-1978.-43, № 11 - С. 2047-2054.

21. Мазо B. K., Ситковский М. B., Янюиин M. Ф. Изучепие взаимодействия белков с окисленными жнрными кислотами // Биоантиокислнтели.— М.: Наука, 1975. -C. $212-216$

22. Singer S., Nicolson $G$. The fluid mosaic model of the structure of cell membranes // Science. - 1974.- 175, N 4023.- P. 720-731.

Xарьков. гос. у'H-T.

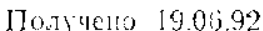

